\title{
THE STATE OF MIGRATORY FISH SPECIES IN OUR WATERS
}

\author{
HERCZEG Béla - SZABÓNÉ BÉRES Beatrix
}

\begin{abstract}
Migratory fishes are important components of the rich wildlife of our waters. Amongst them there are certain species which spend the vast majority of their lives in fresh water (catadromous) and migrate to the sea for spawning, for instance eel species. Others migrate the other way around (anadromous), spending their main growth period and reaching sexual maturity in the sea, then spawning in the freshwaters. Notable representatives of this group are salmonids and sturgeons. The populations of the aforementioned species have decreased significantly in the past decades. The reasons for this can be affected by many factors. Apart from overfishing and the spread of diseases, the dams built on rivers, posing artificial obstacles greatly hinder the achievement of a sufficient natural growth. The outdated dams make approaching the spawning grounds impossible for the fish striving to get there. Having noticed this adverse effect on biodiversity, many of these obsolete dams have already been removed. Where the opportunity arose, fish ladders were constructed, which facilitate the movement of fish. Besides helping the migration, fish ladders provide many species with a habitat.
\end{abstract}

Keywords: migratory fishes, catadromous, anadromous, biodiversity

\section{VÁNDORLÓ HALFAJOK HELYZETE VIZEINKBEN}

\section{Összefoglalás}

Vizeink színes élövilágának fontos alkotói a vándorló halfajok. Közöttük vannak olyanok, amelyek életük jelentös hányadát édesvizeinkben töltik, és szaporodni vonulnak a tengerek sósvizü környezetébe (katadróm fajok), ilyenek például az angolna fajok. Néhányan ennek forditottját követik, azaz tengerekben válnak ivaréretté és ezt követöen a édesvizekben szaporodnak (anadróm fajok), ennek a csoportnak fontos képviselöi a lazac-, és a tokfélék. Az emlitett halak állománya az elmúlt évtizedek során jelentös mértékben csökkent. Az okok között számos tényezö játszhat szerepet. A túlhalászás és a betegségek terjedése mellett a folyókon épített gátak, mint mesterséges akadályok, jelentős mértékben korlátozták a természetes szaporulat kellö mértékü kialakulását. A korszerütlen gátak lehetetlenné teszik az ivóhelyek megközelítését az oda igyekvö halak számára. Felismerve a biodiverzitásra gyakorolt kedvezötlen hatásukat, közülük már sokat elbontottak, illetve ahol erre lehetöség adódott hallépcsöket épitettek, megkönnyítve ezzel a halak vándorlását. A hallépcsők a vándorlás segitése mellett sok faj számára élöhelyet is biztositanak.

Magyar nyelvü kulcsszavak: vándorló halfajok, katadróm, anadróm, biodiverzitás JEL kód: $Q 15$ 


\section{Introduction}

October 24, 2020 marks the latest World Fish Migration Day, an international day held biennially. On this day, we celebrate those fish species that travel long distances in our rivers to reproduce and thus preserve their race. However, many of them do not reach this ultimate goal and the reductions seem nearly catastrophic. Many of the causes of this loss can be attributed to overfishing, poaching, the decrease in water quality and the artificial obstacles, which appear to bring about irreversible decline. The dams as artificial obstacles are considered to be the primary causes of this situation. Currently, tens of thousands of barriers are built on European rivers that have a really adverse effect on the natural state of waters and obstruct the migratory paths of fish. This state can grow worse as, at present, thousands of dams are being built, or planned to be built across the rivers of the continent.

\section{Material and methods}

Based on the available sources, the characteristics of our migratory species are briefly reviewed, building on the special features of these species to overview the current situation [SZÖKE, 2015]. The attempts for improvement and their probable effects are presented and evaluated, highlighting the main representatives of eels, sturgeons and salmonids [BERINKEY, 1966].

\section{Results}

\section{The characteristics and state of sturgeons}

Sturgeons belong to the family of Acipenseridae, they are the eponymous family of the class of ray-finned fishes (Actinopterygii) and the order of Acipenseriformes.

More than twenty species are in this taxon, some of them are the sterlet (Acipenser ruthenus), shown in Picture 1, the kaluga (Huso dauricus) and the beluga sturgeon (Huso huso). The names of the two biggest genera, Acipenser and Huso are often used to refer to this family.

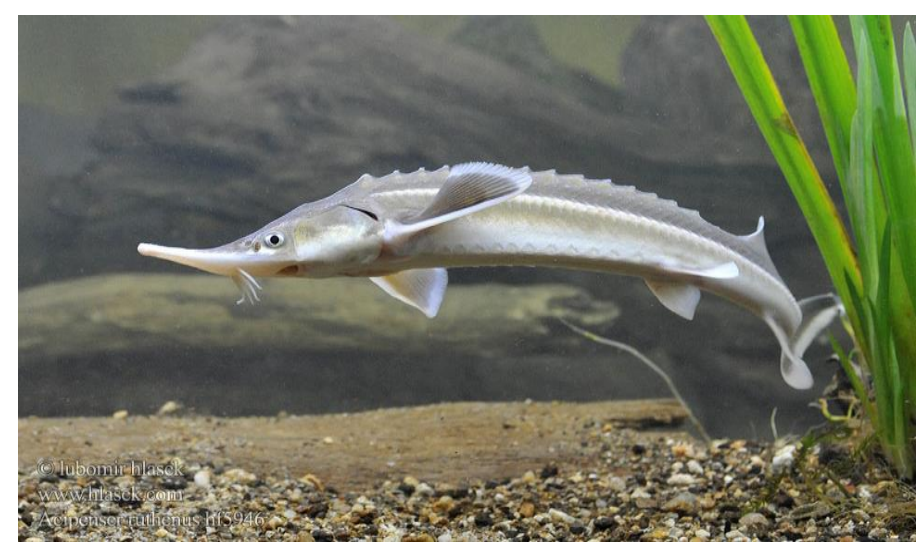

Picture 1: Sterlet

Source: http://www.hlasek.com 


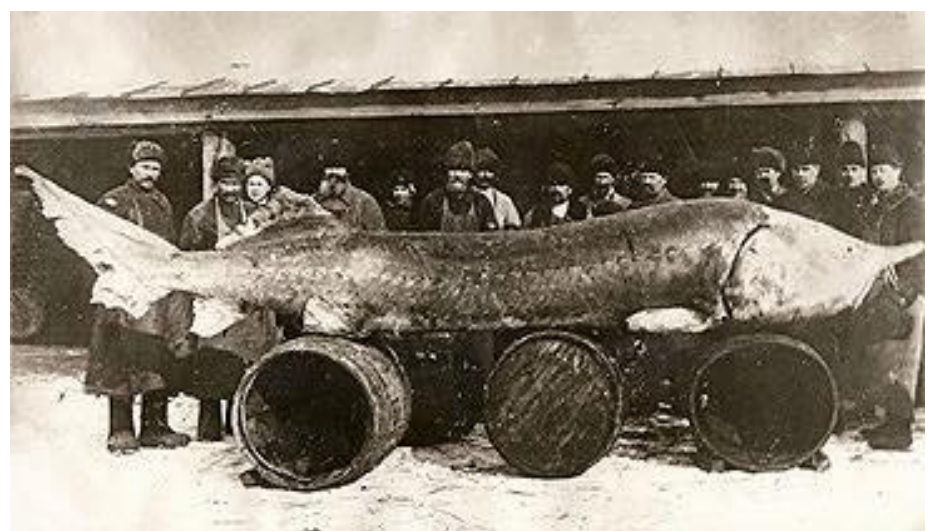

Picture 2: Record-setting beluga sturgeon

Source: vizafogo.blog.hu

The photo depicting a 7.2 m long beluga sturgeon (Picture 2) was made in 1921, it is very likely, though that this fish was caught in the Volga Estuary in Russia, not in the River Danube.

Their representatives are amongst the most ancient fish species, as their emergence dates back to the Mesozoic era, to more than 200 million years ago, the age of dinosaurs. They typically occurr in the subtropical seas of North America, Eastern Europe and Asia. Sturgeons are essentially migratory, but smaller populations of certain species are non-migrant. Saltwater species in a large extent wander to the rivers to spawn. The biggest sturgeon population lives in the Caspian Sea. Fishing for these species has an age-old history in Hungary, they had a significant place in the nourishment of the inhabitants in the Carpathian Basin [HERMAN, 1888]. The 'golden age' of sturgeon fishing was in the first half of the last millennium, which was followed by a decrease in fish stocks [BARTOSIEWICZ, 1997]. By the end of the $20^{\text {th }}$ century, after the building of the Iron Gates barrage (Picture 3) (1970, 1984), the remnant sturgeon populations in the middle Danube completely collapsed.

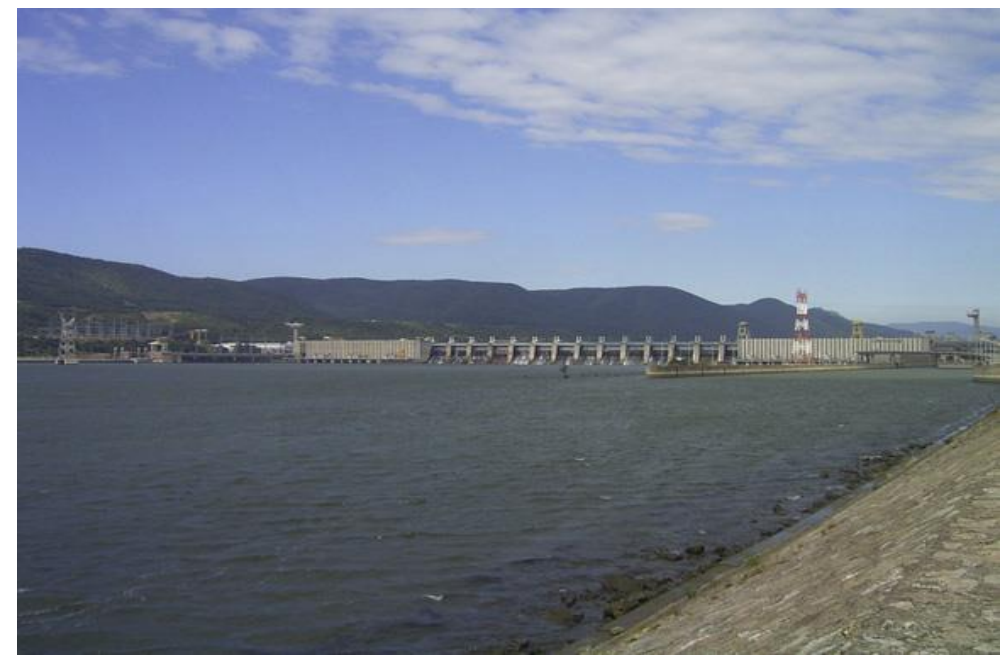

Picture 3: Iron Gate I Hydroelectric Power Station Source: Wikipédia

At present, the beluga sturgeon (Huso huso) and the starry sturgeon (Acipenser stellatus) are almost extinct, moreover, the non-migratory forms of the bastard sturgeon (A. nudiventris) and the Russian sturgeon (A. gueldenstaedti) are critically endangered due to their extremely rare occurrence. Nowadays, only the sterlet (A. ruthenus) remained in our waters and may be fished [GUTI - GAEBELE, 2009]. 
The exploitation of sturgeons has a great role in the decline of numbers, since their meat and the valuable caviar made from their eggs make their fishing highly profitable. That is the reason why their poaching is still widespread, further decreasing fish stocks. Their life cycle may contribute to this decline as well. In general, they are large and long, and, compared to other fish species, they live considerably longer. In connection with that, they reach maturity late, around 6 to 25 years old, so there are fewer individuals that can spawn because of overfishing. Sturgeon spend their whole lives in fresh water. Even though some species are migratory, they wander into freshwater rivers as well.

Based on the catch data and estimates of 2001 , during the $20^{\text {th }}$ century, the world population decreased at least by $70 \%, 13$ species became endangered and 2 are on the verge of extinction. The volume of annual fishing in the past three decades has shrunk from 30000 tons to 500-1000 tons, with the caviar product dropped from 3000 tons to only 100-200 [FELEDI - GYALOG, 2016].

\section{The characteristics and state of eels}

Eels (Anguillidae) belong to the superclass of bony fish (Osteichthyes), the class of ray-finned fish (Actinopterygii) and the order of Anguilliformes, containing 19 species therein.

The species of the family have an elongated body with no ventral fins. The transparent larvae, leptocephali are considerably different from the adult forms. They possess either very small scales or are scaleless and their ancient swim bladder has an air duct connecting it to the foregut.

The European eel (Anguilla anguilla) is indigenous to Western- and the northern part of Central Europe, although with introductions, it can be found in almost every European country. It constitutes the genus Anguilla with eighteen other species, which is the only one in the family (Anguillidae). The name of the species, anguilla comes from the Latin word anguis (snake), conjoined with a diminutive affix [HARKA - SALLAI 2007].

Concerning their behavior, they are catadromous species, meaning that spawning takes place in the sea, but they spend the vast majority of their lives in fresh water. Out of the altogether 19 species of eels (Anguillidae), only one is native to Hungary (European eel). In 1967, Erik Bertelsen managed to identify the approximate coordinates of the spawning ground of eels. According to his data, the spawning likely occurs in the Sargasso Sea, at the intersection of the Tropic of Cancer and the $60^{\circ}$ meridian of west longitude. The exact depth of spawning is currently unknown, but based on the larvae catch data, it is estimated to be between 200 and $500 \mathrm{~m}$, where most of the leptocephali were found.

Eel larvae make a long journey to Europe, partly via the Gulf Stream. Eels undergo many color changes (metamorphoses) through their life cycles, the larvae ("glass eel") are virtually transparent (Picture 4), after entering freshwater, they become yellowish elvers, then change to vivid olive green, which gradually gets darker grayish green over 2-3 years (green elver). The adult predator carries bronze-brown shades, then the migratory form takes on silvery hues ("silver eel"). Depending on their habitat, they differentiate into long-headed, omnivorous or broad-headed carnivorous forms and their skin gets thicker.

Exceptionally, eels can grow to more than one meter in size, but on average 60-80centimeter-long individuals are considered mature. Their diet is essentially predatory and, because of their bottom-dwelling nature, they feed on small animals at the bottom of the water. The main items on the diet of eels are annelids, insect larvae, mollusks, crustaceans, small fish and frogs. Their food consumption varies from season to season. They forage for crustaceans from March to November with a decreasing trend, mollusks from late summer to November, and fish mainly in June and July [ÖRDÖG et al., 2011]. The European eel is a very long-lived species, and can live for more than 50 years when it sets out to the spawning grounds. That is 
why the impact of introductions is still felt decades later. Even in 2018, 27 years after the last stocking, the trap at the mouth of the Sió caught 55 tonnes of eels [PINTÉR, 2002].

Planned introductions in Hungary began in 1961 under the direction of Miklós Ribiánszky, based on the experience of the GDR, and by 1991, 83 million glass eels had been introduced to Lake Balaton. In the first years (1962-63), stocking also took place in estuaries and lakes, the most significant of which was the stocking of 1,736,000 fish in Lake Venice [WIKIPEDIA]. There are still good numbers of eels being caught from these waters after nearly six decades. Today, due to the barriers built on the rivers, the fry are unable to reach our waters and it is reasonable to assume that the long-lived eels caught are from the earlier introductions. The stockings were stopped in 1991, due to the following protests over the large fish mortalities in Lake Balaton (1985 and 1991) [PÉTER, 2013].

The large-scale introduction of eels has almost completely eradicated many of the native species of Lake Balaton, and many believe that it is not their mere presence, but their greatly exaggerated numbers that have caused the damage to the fauna [ÁCS et al., 2013]. The migration of glass eels has become completely impossible due to the construction of dams in recent decades, and as a result, eels are disappearing from their original habitats. The existing small adult population is also reduced by disease and mortality due to water pollution. Even silver eels, which are ready to spawn, cannot reach spawning grounds because of the insurmountable barriers posed by dams. These factors reinforce each other, and may make the European eel disappear from our waters. The global eel population declined by $90 \%$ in the second half of the 20th century [PÉTER, 2013].

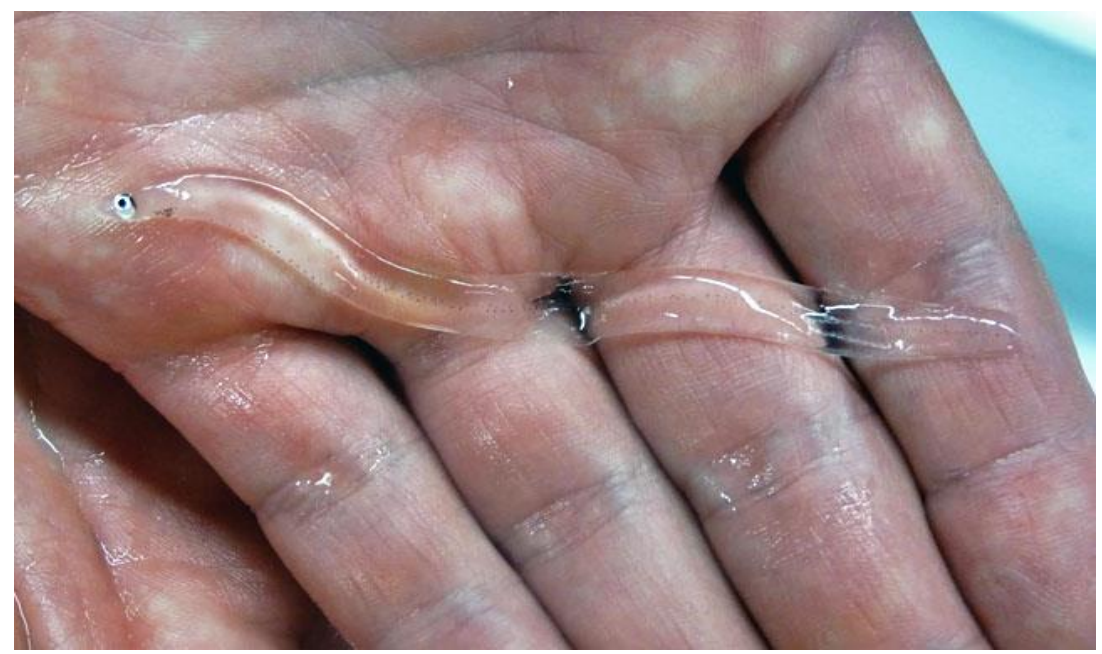

Picture 4: Glass eel

Source: Wikimedia Commons

\section{The characteristics and state of salmonids}

The (atlantic) salmon (Salmo salar) is an anadromous species of the order Salmoniformes in the class of ray-finned fishes (Actinopterygii) and the family Salmonidae. The Salmoninae subfamily includes 7 genera and 97 species, the most numerous being Salmo with 46-49 species and Oncorhynchus with 15 species [PETERSON et al., 2006].

Salmon are found along the coasts and rivers of Western and Northern Europe, from the Bay of Biscay to the Russian region of the Arctic. It is also indigenous to the North Atlantic coasts of the United States and Canada. They remain in freshwater environment for a few years after larvae emerge and then migrate to the sea. 
This species is an active hunter in the sea and often lives in schools. Young salmon feed on insects and other lower river animals. The marine food base mainly consists of fish, such as Ammodytidae species and juvenile herring. Their primary predator is the dusky shark (Carcharhinus obscurus).

The life span of salmon is short compared to the prospects of sturgeon and eel, living only 810 years. The spawning season is between November and February. During migration, it can jump up to 3-5 meters, but even this is not enough to overcome the obstacles of dams. The female uses her tail fin to dig a nest and she lays her eggs in it, which are simultaneously fertilized by the male. Spawning (Picture 5) can last up to two weeks, with the female laying 10 000-40 000 eggs, which take 70-160 days to hatch. After leaving the pebble nest, the fry feed on insect larvae, worms and other aquatic invertebrates. When it reaches about $10 \mathrm{~cm}$, salmon switch to a predatory lifestyle, hunt fish and their body pattern also change. Juveniles stay in freshwater for 1-5 years, then migrate to the sea. On their way to the sea, they turn silvery. Some young males remain in the rivers, although they become smaller, and may also participate in spawning when they reach maturity. The radical decline in salmon populations is triggered by the construction of dams and weirs on rivers, which are built without fish ladders and thus form an impregnable barrier to adult salmon migrating to their spawning grounds and juveniles migrating to the sea. To make matters worse, by the second half of the 20th century, fishing was growing rapidly, accelerating the decline of wild salmon stocks. Despite the fall in catches and the tightening up on fishing regulations, demand for salmon did not fall. Favorable market opportunities will soon give rise to mushrooming salmon farms. The number of salmon farmed is currently estimated at 300 million. The sad fact is that the wild population, previously calculated to be of a similar magnitude, is now approximately only 3.5 million [MARSI, 2014].

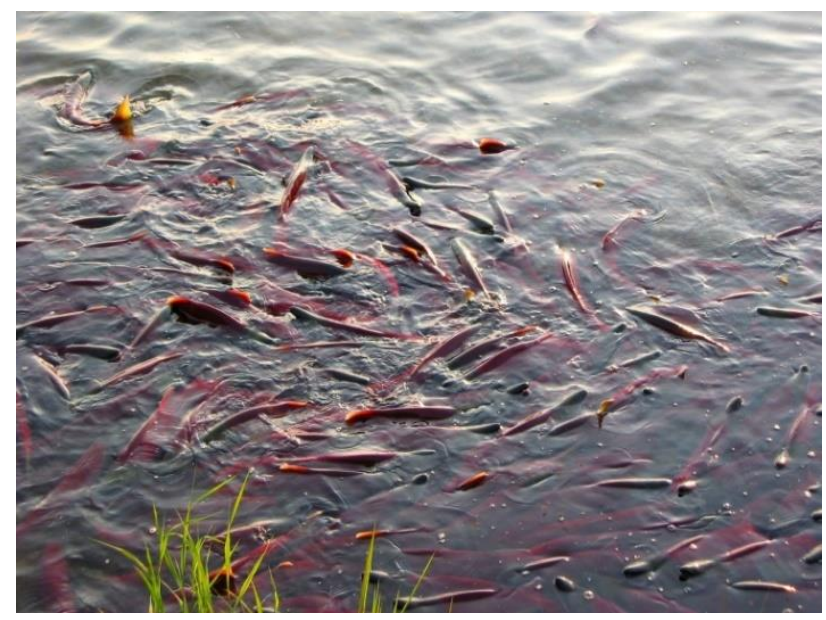

Picture 5: Spawning of salmon

Source: https://magyarmezoga

\section{Main causes of decline in migratory species ("Who's to blame?")}

The term "overfishing" does not really capture the full range of problems associated with it. Growing market demands and favorable economic parameters have led to a boom in the fishing industry. However, this was not matched in time by a flexible response from the monitoring and regulatory system.

The regulation has been delayed, only to follow the decline in stocks from a significant distance, which is evident from the drop in catch data. One of the most typical segments of the environmental problems of overpopulated cities, especially those around rivers, is the very 
diverse arsenal of pollution of living waters [POLEKSIC et al., 2010]. A striking example of this is the increase in cocaine pollution in Western European rivers, which is causing documented damage, muscular deformities and developmental disorders in one of our migratory species, the eel [24.HU].

Dams are indeed invincible obstacles for migratory species, limiting the movements of both anadromous and catadromous fish, and are a hindrance for both juveniles and mature individuals trying to reach spawning grounds. Their role stands out among the inhibiting factors precisely because they make population renewal almost impossible. These artificial barriers make the effectiveness of programmes to restore migratory populations doubtful. This is one of the main reasons why reintroduction projects are unable to increase the numbers of migratory populations. "The time for dams in Europe is over, with some 4,500 'blockades' of various sizes already removed." (Andreas Baumüller, WWF)

Unfortunately, in reality, the situation has not improved considerably, because several times as many as the already disassembled dams are still in operation, and only the obsolete, uneconomical dams have been dismantled.

Hydropower accounts for nearly a quarter of all energy use in the EU [TAMÁS - BLASKÓ, 2008]. There is therefore little chance of the dams being completely removed.

\section{Can the migrants be saved? Is there a solution?}

The priority is to clear the route, or at least provide an escape route for the migrants. Newly built dams should not be constructed without fish ladders, and existing dams should be equipped with this by-pass as soon as possible. The investment cost of building such extra erections is negligible, but it is the only option for the fish.

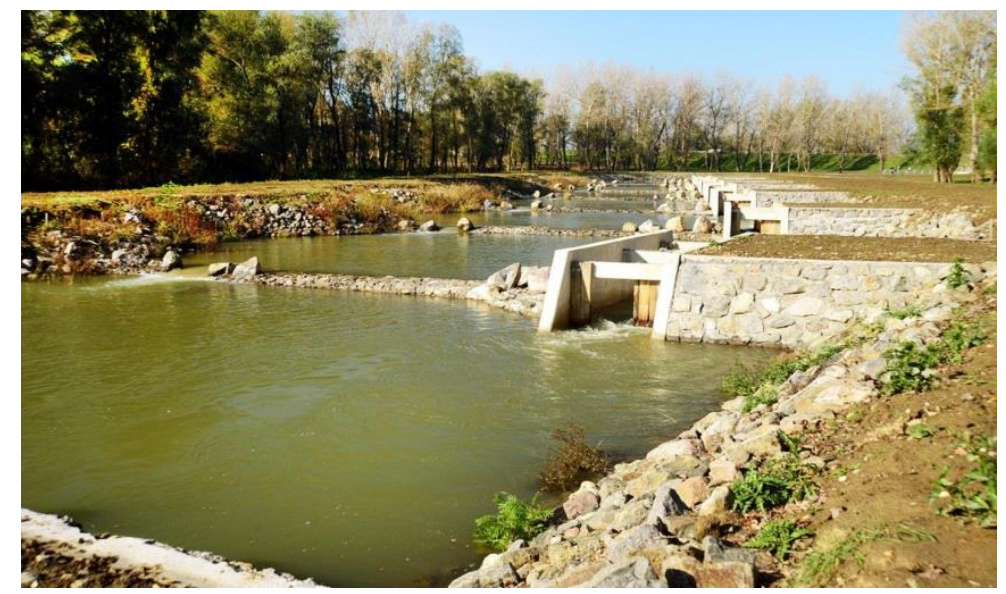

Picture 6: Fish ladder at the Kisköre Dam

Source: http://gyereatiszatora.hu

Tightening up fishing rules and introducing a total ban on certain species is necessary, as it is no use giving the green light for catching the last fish.

The role of aquaculture in serving growing consumption will continue to grow. Artificial reproduction and rearing of sturgeons have a long history going back several decades. Sturgeon meat supply has increased 2.5 times from 30,000 to 75,000 tons compared to the $1980 \mathrm{~s}$. Caviar supply is still only 250 tons, which is only $10-15 \%$ of the 3,000 tons in the 1980 s [FELEDI GYALOG, 2016]

The Atlantic salmon production in Europe is over 1.5 million tons (BARDÓCZ), mainly owing to Norway, which has a share of over 1.2 million tons. 


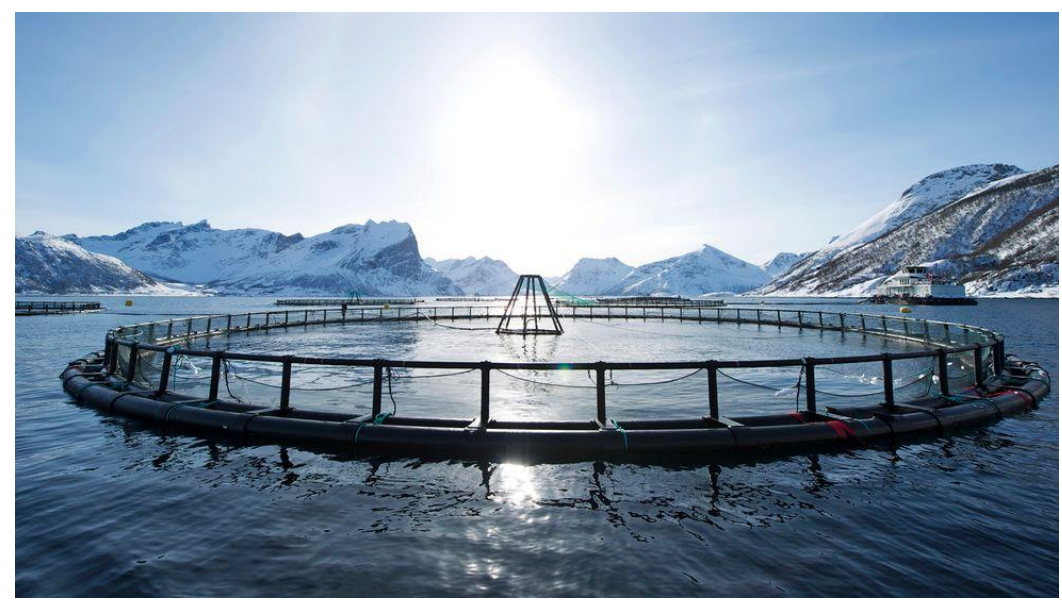

Picture 7: Salmon rearing cage

Source: http://www.nor-oil.hu

Eels are currently not included in aquaculture due to their unique breeding habits, but recent research has reported successful artificial reproduction.

Researchers in Gödöllö have reached the goal in artificial reproduction of the European eel by induced propagation (artificial induction of sexual maturation): the eggs hatched into larvae. This result could be the basis for the development of artificial reproduction technology.

\section{Conclusions}

Populations of migratory fish species have dwindled to a fraction of their former size over the past decades. The causes of the decline, overfishing, pollution and artificial barriers built on rivers synergistically accelerated the deterioration. Many of the formerly dominant species have also become endangered. The role of dams, built in the tens of thousands, which make migration completely impossible and prevent the renewal of the population, is one of the most important inhibitory factors. The too late reaction of politics and the delay in tightening up the regulatory system is certainly contributing to the current situation. The decline in wild populations and the fall in catches have led to a boom in artificial fish meat production. Intensive production can relieve the pressure on wild populations by meeting consumer demand and, for some species, provide a basis for reintroduction. The chances of recovering migratory species through isolated actions are low, based on experience to date. Coordinated international programmes covering all details are needed to ensure that our anadromous and catadromous species remain part of the fish fauna and do not disappear from our waters permanently. 


\section{References}

1. ÁCS B.- SPECZIÁR A.- BOCZONÁDI ZS.- URBÁNYI B.- MÜLLER T. (2013): Az angolna (Anguilla anguilla L.) táplálkozása a Balaton parti övében, Pisces Hungarici 7. , $65-71$.

2. BARTOSIEWICZ L. (1997): A honfoglaló magyarok húsfogyasztása (Meat consumption by conquering Hungarians). In: "Nyereg alatt puhitani ...?" avagy Vendéglátási és étkezési szokások a honfoglaló magyaroknál és a rokon kultúrájú lovasnépeknél címü 1996. október 10-11-i rendezvénysorozat tudományos konferenciájának tanulmányai. Budapest: Kereskedelmi, Vendéglátóipari és Idegenforgalmi Föiskola. pp. 135ff.

3. BERINKEY L.(1966): Halak Pisces. In: Magyarország állatvilága (Fauna Hungariae), XX. kötet, 2. füzet. Budapest: Akadémiai Kiadó, p. 134.

4. GUTI G. - GAEBELE T. (2009): Long-term changes of sterlet (Acipenser ruthenus) population in the Hungarian section of the Danube. Opuscula Zoologica Instituti Zoosystematici et Oecologici Universitatis Budapestinensis, 40(2), 17-25.

5. FELEDI T. - GYALOG G. (2016): Aktualitások a toktermelésben. Gödöllő: VI. Gödöllöi Halászati-Horgászati Szakember Találkozó, pp 1-32.

6. HARKA Á. SALLAI Z. (2007): Magyarország halfaunája. Source: https://regi.tankonyvtar.hu/hu/tartalom/tkt/magyarorszag-halfaunaja/adatok.html

7. HERMAN O. (1887): A magyar halászat könyve I-II. Budapest: Királyi Magyar Természettudományi Társulat.

8. HERMAN O. (1888): A halgazdaság rövid foglalatja. Budapest: Királyi Magyar Természettudományi Társulat.

9. MARSI Z. (2014): A hal, amiből tizedannyi él szabadon, mint ketrecben. Sourse: https://hirmagazin.sulinet.hu/hu/eletmod/a-hal-amibol-tizedannyi-el-szabadon-mintketrecben.

10. PÉTER A. (2013): Unokáink sem fogják enni az angolnát. Source: https://www.origo.hu/tafelspicc/20131204-unokaink-sem-fogjak-enni-az-angolnat.html

11. PETERSON D. - VECSEI P. - HOCHLEITNER M. (2006): Threatened fishes of the world: Acipenser ruthenus Linnaeus, 1758 (Acipenseridae). Environmental Biology of Fishes, September. DOI:10.1007/s10641-006-6659-1

12. POLEKSIC V. - LENHARDT M. - JARIC I. - DJODJEVIC D. - GACIC Z. CVIJANOVIC G. - RASKOVIC B. (2010): Liver, gills, and skin histophatology and heavy metal content of the Danube sterlet (Acipenser ruthenus Linnaeus, 1758). Environmental Toxicology and Chemistry, 29(3), 515-521. DOI: 10.1002/etc.82

13. TAMÁS J., BLASKÓ L. (2008): https://regi.tankonyvtar.hu/hu/tartalom/tamop425/0032_kornyezettechnologia/adatok.ht $\mathrm{ml}$

14. PINTÉR K. (2002): Magyarország halai. Budapest: Akadémiai Kiadó.

15.SZÖKE V. (2015): Bajszok és vértek a mélyből. Source: https://mttmuzeum.blog.hu/2015/07/29/bajszok_es_vertek_a_melybol_i.

16. ÖRDÖG V. - HANCZ CS. - BERCSÉNYI M. - SZATHMÁRI L.- HĀVASI M. (2011): Haltenyésztés. Source: https://dtk.tankonyvtar.hu/handle/123456789/13059.

17. URBÁNYI B. (2016): Lazacfélék tenyésztése. Source: https://docplayer.hu/14267093Lazacfelek-tenyesztese.html.

18. WIKIPEDIA. Lake Balaton. In the first years (1962-63), stocking also took place in estuaries and lakes, the most significant of which was the stocking of 1,736,000 fish in Lake Venice. Source: https://hu.wikipedia.org/wiki/Vaskapu-szoros.

19. 24.HU Zöldövezet rovat. Source: https://24.hu/tag/zoldovezet/ 


\section{Author(s)}

\section{Dr. Béla HERCZEG}

college professor, $\mathrm{CSc}$

Hungarian University of Agriculture and Life Sciences, Károly Róbert Campus, Institute of Sustainable Development and Management

H-3200 Gyöngyös, Mátrai út 36. Bulding ”A” Door 1.409

Herczeg.Bela@uni-mate.hu

\section{Dr. Beatrix SZABÓ-BÉRES}

\section{assistant professor, $\mathrm{PhD}$}

Hungarian University of Agriculture and Life Sciences, Károly Róbert Campus, Institute of Environmental Sciences, Agroecology Group

H-3200 Gyöngyös, Mátrai út 36. Bulding "A” Door 1.406

Szabone.Beres.Beatrix@uni-mate.hu 